\title{
Chapter 16 \\ More Than Cereal-Based Cropping \\ Innovations for Improving Food \\ and Livelihood Security of Poor Smallholders \\ in Marginal Areas of Bangladesh
}

\author{
Mohammad Abdul Malek, Mohammad Syful Hoque, Josefa Yesmin, \\ and Md. Latiful Haque
}

\begin{abstract}
Following the marginality approach developed at ZEF, we identified five underperforming sub-districts in Bangladesh, where poverty and other socioeconomic dimensions of marginality are widespread, but agricultural potential is also high. Results from extensive quantitative and qualitative surveys suggest that development strategies in these areas should focus on three pathways: agricultural intensification, income diversification and agricultural diversification based on options available for the smallholders in the localities. Cereal-based technology under agricultural innovations could be part of the solution, but should be integrated into other income diversification and agricultural diversification strategies. Intensive crop systems, hybrid seeds, water management technologies, non-crop farming, non-farming enterprises are suggested as potential technology innovations for the study areas.
\end{abstract}

Keywords Marginality - Agricultural potential - Development strategies • Agricultural intensification • Income diversification

\footnotetext{
M.A. Malek (ه)

BRAC Research and Evaluation Division (RED), Dhaka, Bangladesh

University of Bonn-Center for Development Research (ZEF), Bonn, Germany

e-mail:malekr25@gmail.com

M.S. Hoque • J. Yesmin • Md. L. Haque

BRAC Research and Evaluation Division (RED), Dhaka, Bangladesh

e-mail: israhat@gmail.com; yesmin.josefa@gmail.com; latiful214@gmail.com

F.W. Gatzweiler, J. von Braun (eds.), Technological and Institutional Innovations for Marginalized Smallholders in Agricultural Development,
}

DOI 10.1007/978-3-319-25718-1_16 


\section{Introduction}

Although Bangladesh has made some remarkable achievements in reducing poverty and improving social and economic outcomes in recent decades, about one-third of the rural population still lives below the upper poverty line, most of whom depend on agriculture as their primary source of income. Compared to favorable areas, a quite dismal picture prevails among the marginal areas in Bangladesh. One of the reasons for their poverty is the low productivity that results from sub-optimal use of inputs and other technologies in agriculture. To foster agricultural productivity and rural growth in those lagging regions, technological innovations have to reach all strata of the poor among small farming communities, who we will refer to hereinafter as smallholders (SHs), in rural Bangladesh. For that purpose, opportunities in technology need to be brought together with systematic and location-specific actions related to technology needs, agricultural systems, ecological resources and poverty characteristics to overcome the barriers that economic, social, ecological and cultural conditions can create. As the first step of an ex-ante assessment of technology innovations for inclusive growth in agriculture (TIGA), a project at the Center for Development Research (ZEF), Bonn, in collaboration with BRAC and partners in India, Ethiopia and Ghana, we followed the mapping approach and identified underperforming areas, hereinafter referred to as marginality hotspots with agricultural potential. Those areas are underperforming areas, i.e., rural areas in which the prevalence of poverty and other dimensions of marginality are high, but agricultural potential is also high, since in such areas, yield gaps (potential minus actual yields) are high and productivity gains (of main staple crops) are likely to be achieved (Malek et al. 2013). The marginality mapping presented in the analyses attempted to identify areas with a high prevalence of societal and spatial marginality - based on proxies for marginality dimensions representing different spheres of life - and high (un(der)utilized) agricultural (cereal) potential. The overlap between the marginality hotspots and the high (un(der)utilized) agricultural potential shows that Rajibpur (Kurigram), Dowarabazar (Sunamgonj), Porsha (Naogaon), Damurhuda (Chuadanga), Hizla (Barisal), Mehendigonj (Barisal), Bauphal (Patuakhali) and Bhandaria (Pirojpur) are the marginal areas where the greatest productivity gains could be achieved.

As the next step of TIGA, those identified marginality hotspots with agricultural potential could be used in combination with other instruments in order to improve targeting and priority setting for an agricultural growth productivity program. Thus, this paper aims to address the following research questions:

(1) Why has the agricultural potential in those areas not yet been made use of? (2) Who are the poor SHs? Which income strata and segments of the rural poor (by agri-ecological and socio-economic clusters) can be found in those areas? (3) What are the strategic options already available for each segment? (4) Which segments of poor SHs could be eligible for agricultural (crop) productivity programs? (5) What are the technology innovations for each segment of the poor? 
To address these research questions, we followed the conceptual framework and theory of change for the TIGA project, as elaborated in section "Conceptual Framework and Methods for Analysis". Then, a selection of study areas, a sample for assessment, and survey methodology are discussed in section "Selection of Study Areas, Sample for Assessment and Survey Methodology". Results with analytical techniques are elaborated in section "Results and Discussion". And, finally, we draw some conclusions for institutional and technological innovation to take place.

\section{Conceptual Framework and Methods for Analysis}

With reference to the conceptual framework and theory of change as developed for the Agricultural Technology Innovations for Inclusive Growth in Agriculture (TIGA) project, once the marginality hotspots with agricultural potential are identified, then the poor SHs (the eligible population for any agricultural growth productivity program) are identified in those areas, and stratification according to income criteria is carried out, e.g., subjacent poor are those with incomes between $\$ 1$ and $\$ 1.25 /$ day, medial poor: between $75 \phi$ and $\$ 1 /$ day, and ultra-poor: below $75 \phi /$ day. ${ }^{1}$ Those stratifications of the poor SHs are validated by participatory wealth-ranking and/or self-reported perceptions. At this stage, the poor SHs from each stratum are allocated to five broad strategic options (Fig. 16.1):

(A) agricultural intensification through improving current farming system performance by means of innovations (yet to be identified),

(B) agricultural diversification through changing current farming system and/or shifting to another,

(C) income diversification through progressing along the value chain, for example, by shifting from being a farmer to working as an agro-dealer, or diversifying income from the non-agricultural sector (e.g., by non-farm wage employment or migrating to other areas/abroad)

(D) leaving the agricultural sector completely

This allocation of poor SHs from different strata is carried out parallel to the livelihood assets and need assessment. As it is widely recognized that development strategies for sustainable intensification in marginality hotspots with agricultural potential need a careful adjustment of resource use at the field farm, household and village levels, we need to look for a portfolio of activities and technologies that guarantee input efficiency and labor productivity (Ruben et al. 2007). The sustainable livelihoods framework (SLF) developed by DFID (2000) is used to improve our understanding of the livelihoods of the poor SHs. The livelihoods approach places households and their members at the center of analysis and decision-making, with the implication that the household-centered methods of analysis must play a

\footnotetext{
${ }^{1}$ This stratification needs to be adjusted to national poverty lines in each study country.
} 


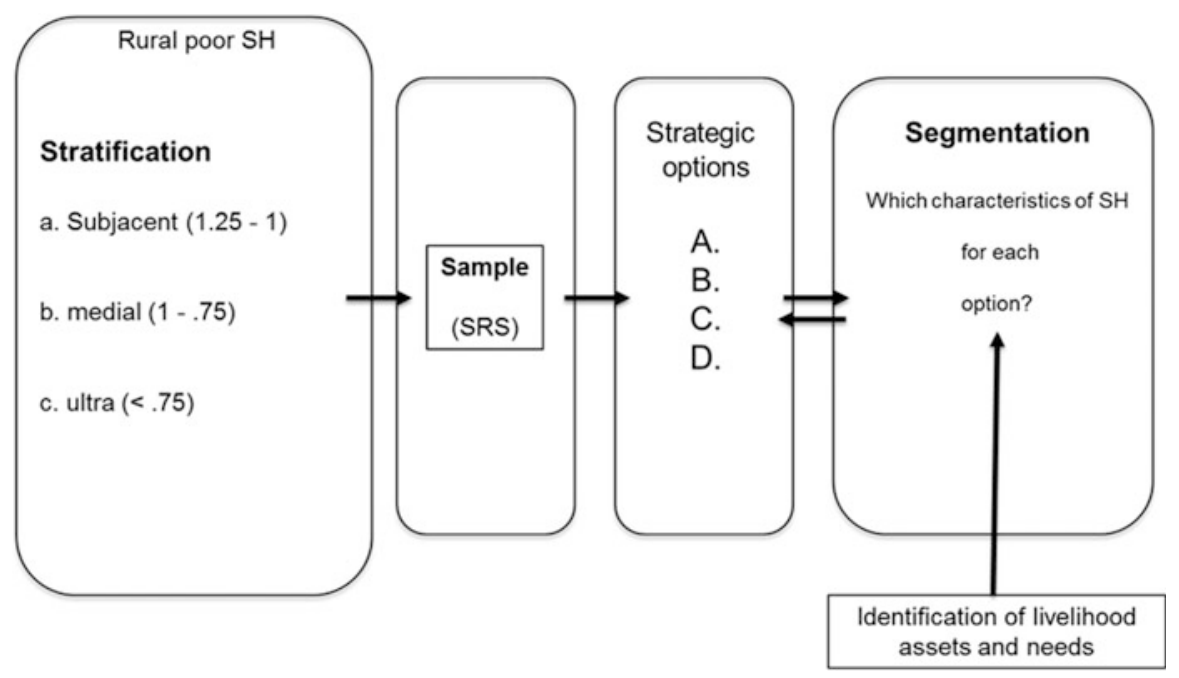

Fig. 16.1 From stratification to segmentation (Source: Personal communication with Franz Gatzweiler)

central role in developing an understanding of livelihood strategies. Applying SLF highlights the multilayered interactions between technologies and the vulnerability context of households - their asset base, access to social capital, and livelihood strategies. However, additional aspects of culture, power, and history are also integrated to understand the role of agricultural research in the lives of the poor (DFID 1999; OECD 2001; Carney 1998).

The sustainable livelihood framework

- provides a checklist of important livelihood issues, with particular focus on current farming practices and agricultural technology use, and sketches out the way these link to each other;

- draws attention to core influences and processes; and

- emphasizes the multiple interactions between the various factors which affect the livelihoods.

The framework is centered on people. It does not work in a linear manner and does not try to present a model of reality. Its aim is to help stakeholders with different perspectives to engage in structured and coherent debate about the many factors that affect livelihoods, their relative importance and the way in which they interact. This, in turn, should help in the identification of appropriate entry points for support of livelihoods (DFID 1999). People and their access to assets are at the heart of livelihood approaches. In the original DFID framework, five categories of assets or capitals were identified, these original categories being: Human capital, natural capital, financial capital, physical capital, social capital- these livelihood assets are the locked potentials of the SHs. 
Within the framework, assets are both destroyed and created as a result of the trends, shocks and seasonality of the vulnerability context. Farmers' livelihood assets are affected by the vulnerability context: critical trends, shocks and seasonality - over which they have limited or no control and which are parts of the barriers identified in the next step:

- Critical trends may (or may not) be more benign, though they are more predictable. They have a particularly important influence on rates of return (economic or otherwise) to chosen livelihood strategies.

- Shocks can destroy assets directly (e.g., in the case of floods, storms, civil conflict). They can also force people to abandon their home areas and dispose of assets (such as land) prematurely as part of coping strategies.

- Seasonal shifts in prices, employment opportunities and food availability are some of the greatest and most enduring sources of hardship for poor people in developing countries.

The livelihood analysis tries to develop a full understanding of all dimensions of the vulnerability context, the aim being to identify those capital assets, trends, shocks and aspects of seasonality that are of particular importance to livelihoods of the poor SHs. Efforts can then be concentrated on understanding the impact of these factors and how negative aspects can be minimized. A need assessment can, in addition, identify demands, wants and requirements for improving the quality of current livelihoods. Such needs can be discrepancies between current and needed or desired conditions of SHs, and they are assessed to ensure that technological innovations which are economically possible also match the wants and aspirations of the poor - an important aspect which is also captured by allocating the strategic options to the surveyed SHs.

Then, allocation of the different strategic options to the poor SHs is done in a participatory manner and supported by agronomic calculations based on household data from the livelihood assets and needs assessment to ensure that the options are realistic (no wish lists) and economically viable for each of the actors from different strata. Trade-offs may need to be made between subjective and rational choices. The SHs being allocated different strategic options come from different strata. By means of their characteristics, the segments are defined for each strategic option. Segmentation is necessary to identify suitable technology innovations - innovations which match the characteristics of each segment and thereby contribute to achieving the overall goal of increasing productivity. For example, all SHs allocated option A own land, or lease land, or are sharecroppers, and each belong to a different income category. Land and income, for example, define different segments which can be further defined by additional characteristics, such as family members, level of education and social status. After this step in the assessment, we know which strategic options are available for which strata of the poor and which characteristics the poor have in each option category (segment). Finally, poor SHs from different strata are segmented to the strategic options stemming from all-inclusive assessment of household attributes, using cluster analysis for this 
purpose. Some systematic tabulation of perception study and qualitative assessments has been used for identifying technological innovations.

\section{Selection of Study Areas, Sample for Assessment and Survey Methodology}

The marginal areas identified for the assessment are usually bypassed by policymakers due to a generalized convention about the Agro-Ecological Zones (AEZs) as a whole, causing them to receive less attention (Malek et al. 2013). Therefore, marginal (or less-favored or laggard) regions, especially in poor developing countries and emerging economies in Sub-Saharan Africa and South Asia, have recently gained much attention in the development literature (Conway 1999; Fan and Hazell 2000; Pinstrup-Anderson and Pandya-Lorch 1994; Ruben et al. 2007; Pender 2007; Reardon et al. 2012). As mentioned earlier, the first step towards designing systematic interventions is to identify underperforming areas. Identification has been based on a high prevalence of societal and spatial marginality, using proxies for marginality dimensions representing different spheres of life and an overlapping high (un(der)utilized) agricultural (cereal) potential. The available secondary data and household survey data from various sources have been used for the exercise. Figure 16.2 shows that Rajibpur (Kurigram), Dowarabazar (Sunamgonj), Porsha (Naogaon), Damurhuda (Chuadanga), Bhandaria (Pirojpur), Hizla (Barisal), Mehendigonj (Barisal) and Bauphal (Patuakhali) are the marginal sub-districts where the highest productivity gains can be achieved through suitable agricultural technology intervention. These areas are in different AEZs - most of which are agro-ecologically fragile/unfavorable. Among them, Patuakhali, Pirojpur and Barisal are in the Coastal region, Kurigram is in the Northern Char region, Sunamgong is in the Haor region and Naogaon is in the Drought prone areas. Only Chuadanga, among these seven districts, is not in an agro-ecologically vulnerable region, but it is in a food insecure region (HKI and JPGSPH 2011). Another point to note is that 4 out of these 8 sub-districts are adjacent to India's borders, whereas the other 4 sub-districts are located in the coastal region.

Thus, among those eight sub-districts, the first four represent different regions while the latter four represent similar regions (the coastal belt), and among these four, Bhandaria (Pirojpur) would be comparatively less difficult to reach with agricultural technology interventions. Thus, we selected the following five sub-districts to be the study sites for our ex-ante assessment: Rajibpur (Kurigram), Dowarabazar (Sunamgonj), Porsha (Naogaon), Damurhuda (Chuadanga) and Bhandaria (Pirojpur).

Then, we, the research team, visited the localities, assessed the situation, and prepared a list of all marginal villages. Finally, we randomly selected 16 marginal villages for the detail quantitative sample survey. Prior to conducting the in-depth quantitative sample survey, we conducted qualitative surveys in five villages (one 


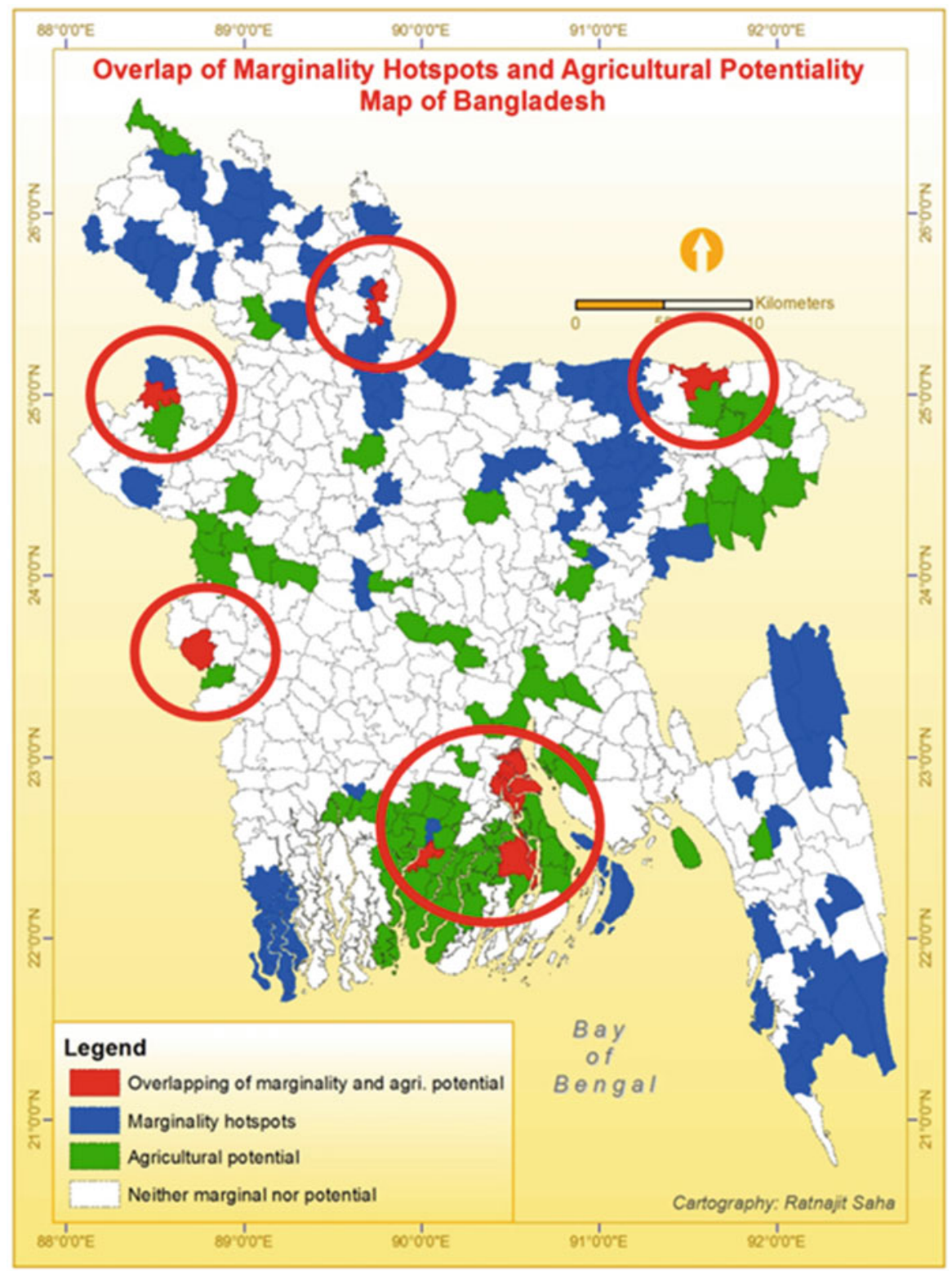

Fig. 16.2 Map of study areas - overlap of marginality hotspots and agricultural potential in Bangladesh

village per sub-district) that included several PRA methods (social and resource mapping, participatory wealth ranking, in-depth interview, focus group discussion) for livelihood assets and needs assessment. Those qualitative data were analyzed through contents analysis, which helps to identify the issues for detailed 
quantitative investigation. At the beginning of the quantitative sample survey, we first conducted a household census (5,855 households) in all 16 villages, collecting some basic information mainly related to household assets for the primary purpose of identifying poor SHs (study population) for the assessment. For this, we analyzed the census data and developed a wealth index ${ }^{2}$ calculated from principal component analysis (PCA) factor scores and found 862 poor $\mathrm{SHs}^{3}$ (study population) for the assessment. From this study population, following a proportionate random sampling, a sample of the poor SHs (357) were drawn for an in-depth quantitative sample household survey (Table 16.1).

\section{Results and Discussion}

\section{Bio-Physical Conditions for the Poor SHs in the Marginal Sub-Districts in Bangladesh: Unused Potentials}

While the national average for cropping intensity is about 180, it is only 144 for the study sample in those five sub-districts- it is extremely low for certain sub-districts (Rajibpur under Charland, Dowarabazar under the Haor basin) - and the rice yield rates in those areas are also very low (Tables 16.2, 16.3, and 16.4). While the major crop season in the so-called typical favorable areas in Bangladesh is dry season (high yielding) irrigated rice, Aman (wet-season) rice (moderate yielding) is the major crop season for three of the five sub-districts. Our results clearly indicate the availability of unused potential for cereal crops. If we see major livelihood opportunities (by seeing the household members engagement/income share to household total income) in a favorable rural area, non-farm business, non-farm wage employment, remittances from abroad and high yielding crops and non-crop farming are the dominant livelihood options (Malek and Usami 2010); however,

\footnotetext{
${ }^{2} \mathrm{~A}$ wealth index indicates the level of wealth which is consistent with expenditure and income measures (Rutstein 1999). The wealth index has been constructed based on the census data on household assets (ownership of durable goods, such as TVs, bicycles and landholdings) and quality of life indicators (water supply and sanitation facilities). A single wealth index has been done based on the following equation (Balen et al. 2010):
}

$$
\mathrm{Ai}=\hat{\gamma} 1 \alpha \mathrm{i} 1+\ldots+\hat{\gamma} \text { noin, }
$$

where $\mathrm{Ai}$ is the standardized wealth index score for $\mathrm{i}^{\text {th }}$ households; $\alpha \mathrm{in}=\left(\mathrm{xin}-\mathrm{x}^{-} \mathrm{n}\right) / \mathrm{SDn}$; $\hat{\gamma} \mathrm{n}=$ Weight (factor score); $\mathrm{xin}=\mathrm{nth}$ asset for household I; $\mathrm{x}^{-} \mathrm{n}=$ Mean of $\mathrm{nth}$ asset for all households; $\mathrm{SDn}=$ Standard deviation for $\mathrm{nth}$ asset for all households.

${ }^{3}$ Poor smallholders: Though we considered a farm size of 2.47 acres to be the ceiling, the average farm size in our sample was 0.53 acres, of which $60.78 \%$ were functionally landless $(<0.50$ acre $)$ farm households, $28.85 \%$ were marginal farm households (0.51-1.00 acre) and $10.36 \%$ were small farm households (1.01-2.50 acres). 


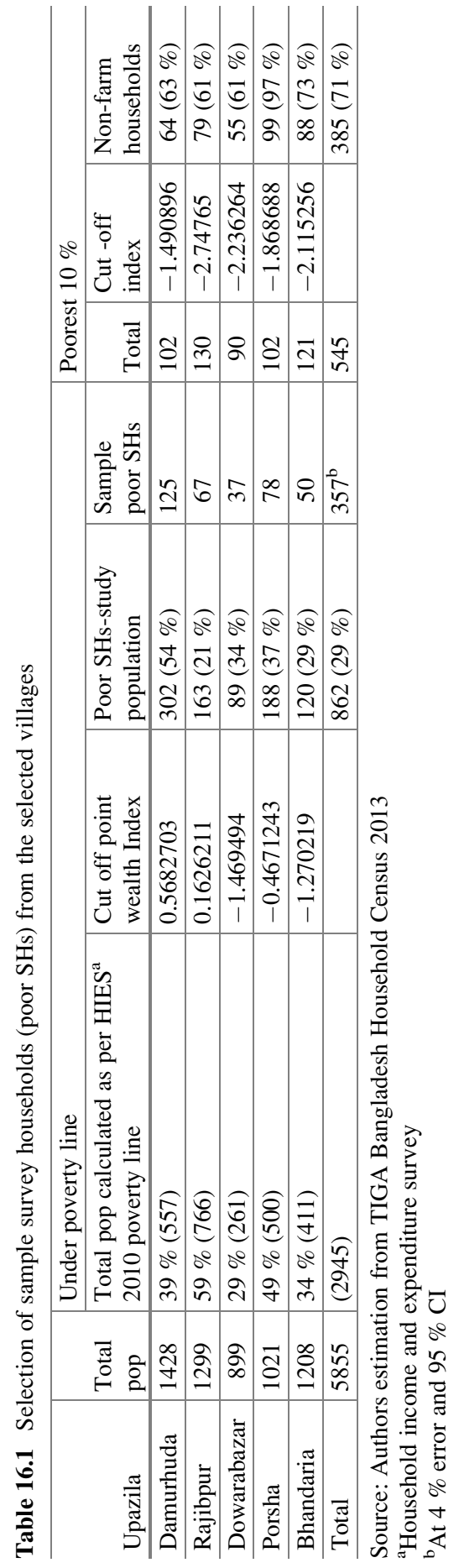


Table 16.2 Farm size, cropped area and cropping intensity of poor SHs in the marginal sub-districts of Bangladesh: 2013

\begin{tabular}{l|l|l|l}
\hline Sub-districts & hh_farm_size (acre) & Cropped area (acre) & Cropping intensity \\
\hline Damurhuda & 0.58 & 0.94 & 159.40 \\
\hline Rajibpur & 0.56 & 0.57 & 100.61 \\
\hline Dowarabazar & 0.79 & 0.95 & 121.99 \\
\hline Porsha & 0.63 & 0.97 & 156.10 \\
\hline Vandaria & 0.93 & 1.49 & 163.57 \\
\hline Total & 0.66 & 0.96 & 144.03 \\
\hline
\end{tabular}

cereal (predominantly rice) farming and low productive agricultural day laboring are the major livelihood options in these sub-districts. The poor SHs in these areas are unable to develop the opportunities of high yielding cereal- and non-cerealbased farming, non-crop farming, non-farm business activities, non-farm wage employment and international migration, realities which came from both qualitative investigation and sample survey. This is not only a result of their adverse geographical location but also their poor capital bases and the unavailability of innovative development interventions in the locality, as will be further explained in a later section. The qualitative investigations suggest that the poor SHs in the marginality hotspots are vulnerable due to their agro-ecological vulnerabilityalmost all five areas face, to some extent, natural calamities (flood, drought, salinity by tidal flow) that discourage farmers from thinking that innovative process and technology might be useful for agricultural production for their livelihoods (Box 16.1). The poor SHs in all areas (except Damurhuda) are usually less motivated for agricultural intensification and also lack agricultural knowledge. Almost all areas face water management and irrigation problems with varying degrees of severity. They are also constrained by their limited connectivity with the main growth centers, poor physical irrigation and extension/communication infrastructure, and power shortages.

\section{Box 16.1: Farmers Are Physically Weak and Naturally Vulnerable}

As can be seen from our qualitative field data collected during March, 2013, most of the farmers who belong to poor or ultra-poor strata groups are physically vulnerable in regards to farming. The majority of them suffer from severe backbone/waist pain and physical weakness at some point during working hours. Abul Hashem is a farmer from Poromesshoripur, Sunamganj who has been living with waist pain for over 12 years. Though it's overburdening for a 50-year-old farmer to do hard work in the agro-field, there is no other way for him to fulfill his function as a household head. To describe his physical condition, Hashem opines, "I am sick and suffering 


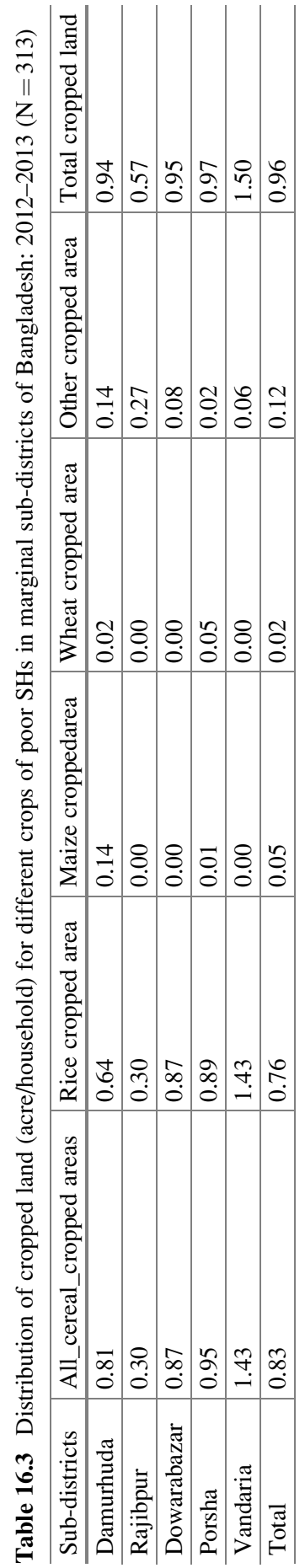


Table 16.4 Yield rate for cereals for poor SHs in marginal sub-districts of Bangladesh $(\mathrm{N}=313)$

\begin{tabular}{l|l|l|l}
\hline Sub-districts & Rice_yield (t/ha) & Maize_yield $(\mathrm{t} / \mathrm{ha})$ & Wheat_yield $(\mathrm{t} / \mathrm{h})$ \\
\hline Damurhuda & 4.50 & 8.87 & 2.93 \\
\hline Rajibpur & 2.79 & - & - \\
\hline Dowarabazar & 3.42 & - & - \\
\hline Porsha & 5.15 & - & 3.16 \\
\hline Vandaria & 2.67 & - & - \\
\hline Total & 4.01 & - & - \\
\hline
\end{tabular}

\section{Box 16.1 (continued)}

from bone decay on the left side of my waist. This doesn't make me feel good in any way. Also I am so weak from working hard in the field because of my age." He seems sicker compared with the other villagers of his age. Tobacco use could be one of the foremost factors affecting his state. Besides this sort of physical sickness and the inability to do the sort of hard work demanded by farming, sometimes farmers have to face a natural barrier to cultivation. According to Hashem, he got a lower amount of production than he had in the previous year. As he states, "Disaster and flood have damaged a large amount of [the] crop this year, which has driven [the] economic and household conditions into a vulnerable state."

\section{Number and Characteristics of the Poor at Each Poverty Strata}

National sources (BBS 2011 show that the population under the upper poverty line, regardless of their farming involvement in those five sub-districts, varies from $34 \%$ to $59 \%$, except in Dowarabazar (haor area) where the figure is nearly equal to national averages $(31 \%)$. Results from the TIGA Bangladesh household census 2013 conducted in 16 villages of 5 marginal sub-districts show that about 3,135 households (54\% of 5,855 total) are SHs, of which about 862 households (27\% of SHs and $15 \%$ of total) are poor SHs who could be eligible for an agricultural productivity improvement program in the marginal sub-districts. From this study population, a sample of $357 \mathrm{SHs}$ has been drawn for the detailed investigation. Then, the sample households have been stratified by quantitative income criteria and validated by participatory wealth ranking and self-reported perceptions. For income criteria, we use both US dollar classification and PPP dollar classification, finding that US dollar classification (e.g., subjacent poor being those with incomes between $\$ 1$ and $\$ 1.25 /$ day, medial poor: between $75 \phi$ and $\$ 1 /$ day, and ultra-poor: below 75 4 /day) is more consistent with self-reported perception (Table 16.5). Table 16.5 suggests that about $12.32 \%$ of the sample belongs to the non-poor category of US dollar income criteria (equivalent to $8.4 \%$ of self-reported 
Table 16.5 Surveyed poor SHs' stratifications in marginal sub-districts with agricultural potential in Bangladesh $(\mathrm{N}=357)$

\begin{tabular}{l|l|l|l}
\hline $\begin{array}{l}\text { Household } \\
\text { status }\end{array}$ & $\begin{array}{l}\text { Self-reported perceptions } \\
(\%)\end{array}$ & $\begin{array}{l}\text { As of US \$ (@ 80.00 } \\
\text { BDT) }\end{array}$ & $\begin{array}{l}\text { As of PPP \$ } \\
(@ 33.53)\end{array}$ \\
\hline non_poor & 8.4 & 12.32 & 63.02 \\
\hline subjacent_poor & 20.17 & 13.73 & 11.2 \\
\hline medial_poor & 55.18 & 17.93 & 8.4 \\
\hline ultra_poor & 16.25 & 57.7 & 18.77 \\
\hline Total & 100 & 100 & 100 \\
\hline
\end{tabular}

Table 16.6 Distribution of poor SHs among selected sub-districts (as of US \$ classification) $(\mathrm{N}=313)$

\begin{tabular}{l|l|l|l|l}
\hline Sub-districts & Ultra poor & Medial poor & Subjacent poor & All samples \\
\hline Damurhuda & $63 \%$ & $23 \%$ & $15 \%$ & $36 \%$ \\
\hline Rajibpur & $71 \%$ & $17 \%$ & $15 \%$ & $19 \%$ \\
\hline Dowarabazar & $63 \%$ & $17 \%$ & $20 \%$ & $11 \%$ \\
\hline Porsha & $72 \%$ & $20 \%$ & $8 \%$ & $20 \%$ \\
\hline Vandaria & $58 \%$ & $21 \%$ & $23 \%$ & $14 \%$ \\
\hline Total & $66 \%$ & $20 \%$ & $15 \%$ & $100 \%$ \\
\hline
\end{tabular}

perception), and thus, the latter analyses are centered on this sample (313 poor SHs). It is also found that the number of subjacent poor is almost the same in both USD income criteria and self-reported perception, but varies significantly for medial and ultra-poor households. Our qualitative participatory wealth ranking exercise also shows that the majority of the households in the sample should be in the ultra-poor category. Thus, we followed the latter analyses based on the USD income classification. Sub-district-wise distribution (Table 16.6) shows that the number of subjacent and medial poor SHs does not differ significantly, but the number of ultra-poor SHs is comparatively higher in Porsha and Rajibpur than it is in the other three sub-districts. Though the overall economic condition in Damurhuda is much better compared to that in Dowarabazar, the similar number of ultra-poor SHs in those two sub-districts may be a result of the fact that, in Damurhuda, poor SHs are more marginalized compared to the better off households. A later section will furnish us with a greater explanation of these facts.

\section{Poor SHs Livelihood Capitals as Per Stratification}

Table 16.7 shows that the poor SHs' capital bases are very poor, but these capitals don't significantly differ quantitatively from different strata (subjacent, medial and ultra-poor). However, qualitative investigations suggest that the majority of the community defined by ultra-poor categories are differentiated from medial to subjacent poor in terms of landholdings/access to farmland, livelihood engagement, 


\begin{tabular}{|c|c|c|c|c|c|c|c|c|c|c|c|c|}
\hline & & $\underset{-1}{8}$ & $\underset{:}{\stackrel{8}{-}}$ & $\begin{array}{l}8 \\
0 \\
0\end{array}$ & $\underset{-}{8}$. & $\stackrel{8}{-}$ & $\underset{-}{8}$ & $\stackrel{8}{-}$ & $\underset{-}{\stackrel{8}{-}}$ & 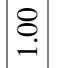 & 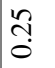 & 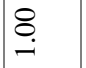 \\
\hline$\stackrel{\infty}{i}$ & 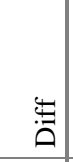 & יְ̃ & $\begin{array}{l}\text { Î } \\
\text { i }\end{array}$ & 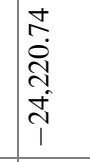 & 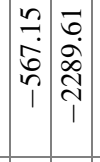 & $\left|\begin{array}{c}\infty \\
0 \\
\infty \\
1\end{array}\right|$ & 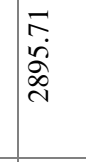 & 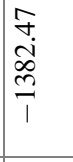 & 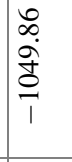 & $\begin{array}{l}\infty \\
0 \\
\infty \\
\tilde{d} \\
i n \\
i n\end{array}$ & 0 & : \\
\hline & 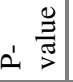 & $\frac{n}{0}$ & : & 8 & $\stackrel{8}{-}:$ & $\frac{0}{0}$ & $\stackrel{8}{\longrightarrow}$ & 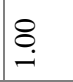 & $\underset{-}{\&}$ & $\stackrel{8}{-}$ & 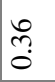 & ñ \\
\hline 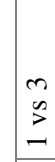 & 表 & $\begin{array}{l}\infty \\
n \\
i \\
i\end{array}$ & $\begin{array}{l}n \\
\hat{n} \\
i\end{array}$ & 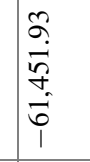 & 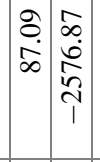 & $\begin{array}{l}\stackrel{0}{a} \\
\underline{n} \\
1\end{array}$ & $\begin{array}{l}\infty \\
\widetilde{3} \\
\infty \\
\infty \\
1 \\
1\end{array}$ & $\begin{array}{l}\frac{\infty}{0} \\
\stackrel{0}{0} \\
\frac{0}{1} \\
\frac{1}{1}\end{array}$ & $\begin{array}{l}2 \\
\text { ले } \\
\hat{n}\end{array}$ & 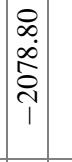 & : & 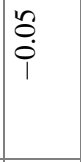 \\
\hline & م) & 苂 & $\underset{-}{\stackrel{8}{-}}$ & 8 & $\stackrel{8}{8}$ & $\underset{8}{\stackrel{8}{-}}$ & 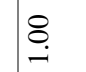 & $\underset{-}{8}$ & İ & : & $\underset{-8}{8}$ & $\underset{.}{8}$ \\
\hline 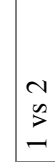 & $\stackrel{\Xi}{0}$ & $\overrightarrow{\bar{m}}$ & $\stackrel{m}{i}_{i}^{i}$ & 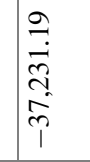 & 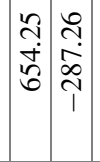 & $\begin{array}{l}\overrightarrow{\hat{e}} \\
\hat{i}\end{array}$ & 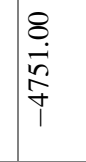 & 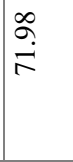 & $\begin{array}{l}\infty \\
\infty \\
\infty \\
\infty \\
0 \\
n \\
n\end{array}$ & 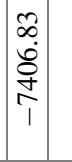 & ठم. & Oे \\
\hline 殀 & की & $\stackrel{8}{9}$ & $\begin{array}{l}\infty \\
\infty \\
i\end{array}$ & $\begin{array}{l}\infty \\
\infty \\
\dot{J} \\
\mathfrak{J} \\
\tilde{y} \\
\end{array}$ & 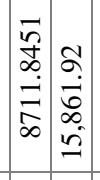 & 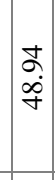 & 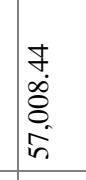 & 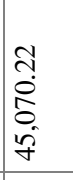 & $\begin{array}{l}0 \\
0 \\
0 \\
\infty \\
\infty \\
\infty \\
\infty\end{array}$ & 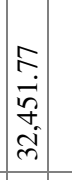 & $\frac{n}{0}$ & $\frac{n}{0}$ \\
\hline 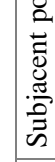 & 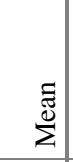 & 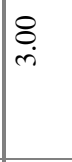 & 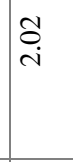 & $\begin{array}{l}\hat{n} \\
\hat{n} \\
\hat{n} \\
\hat{n} \\
\underline{\varrho}\end{array}$ & 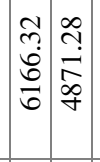 & 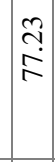 & 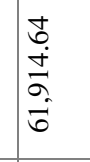 & 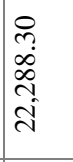 & 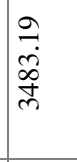 & 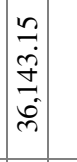 & $\stackrel{\infty}{\stackrel{2}{二}}$ & 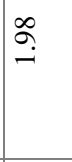 \\
\hline 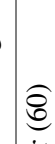 & 合 & 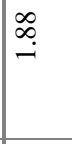 & 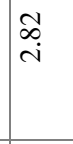 & 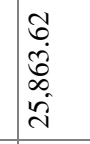 & 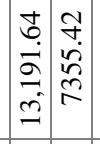 & $\begin{array}{l}\text { ț } \\
\text { : } \\
\text { in }\end{array}$ & $\begin{array}{l}x \\
\infty \\
\dot{D} \\
b \\
i \\
i \\
\text { n. }\end{array}$ & 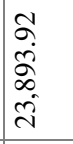 & 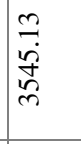 & 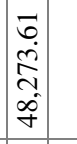 & 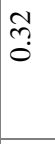 & ปิ \\
\hline 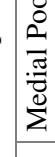 & $\frac{\bar{\sigma}}{\tilde{\sigma}}$ & $\underset{j}{i}$ & $\stackrel{\infty}{\rightarrow}$ & $\begin{array}{l}\stackrel{\rho}{i} \\
\vec{R} \\
\stackrel{R}{i}\end{array}$ & 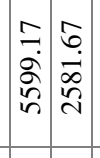 & $\begin{array}{l}\infty \\
\infty \\
\infty \\
\infty \\
0\end{array}$ & $\begin{array}{l}n \\
\tilde{m} \\
\hat{0} \\
\infty \\
\dot{0} \\
\dot{d}\end{array}$ & $\begin{array}{l}\infty \\
\infty \\
\infty \\
\alpha \\
\tilde{n} \\
\tilde{\pi}\end{array}$ & $\begin{array}{l}\tilde{m} \\
\tilde{\tilde{J}} \\
\tilde{N}\end{array}$ & 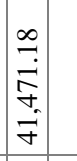 & 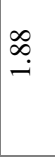 & $\stackrel{2}{G}$ \\
\hline $\begin{array}{l}0 \\
\text { II } \\
\text { II } \\
\mathrm{z}\end{array}$ & की & $\stackrel{\infty}{\stackrel{\infty}{=}}$ & 㝕 & 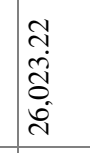 & 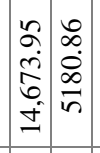 & 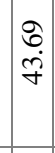 & 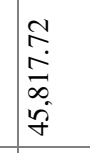 & 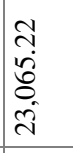 & 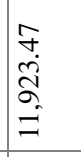 & 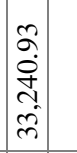 & ఫે & ర్d \\
\hline 递 & 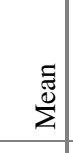 & F & f. & $\begin{array}{l}8 \\
0 \\
\dot{0} \\
0 \\
\dot{q} \\
\dot{q}\end{array}$ & 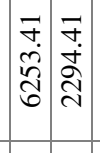 & 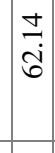 & $\begin{array}{l}n \\
2 \\
2 \\
0 \\
8 \\
0 \\
0\end{array}$ & 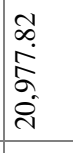 & $\begin{array}{l}\infty \\
\stackrel{\infty}{\vec{n}} \\
\text { in }\end{array}$ & 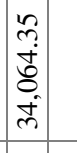 & $\bar{g}$ & $\stackrel{\Omega}{\Omega}$ \\
\hline 5 & & & & 56 & & & 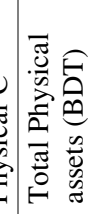 & $\frac{2}{0}$ & 돈 & $\underline{8}$ & & 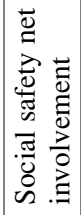 \\
\hline
\end{tabular}


technology adoption, credit accessibility, cell phone use, motivation and communication/networking skills, and physical fitness (Annex 1). Poor SHs are also insecure and vulnerable (Box 16.1).

\section{Poor SHs' Livelihood Opportunities and Income Pattern Across Poverty Strata}

The livelihoods of poor SHs and their households' working members include farming, non-agricultural enterprises, wage employment in the locality, and migration (Annex 2). Rice during the Boro and Aman seasons is a common cereal crop for all strata of SHs in marginal areas. Additionally, the subjacent poor SHs in the Charland produce a limited scale of maize and wheat, while the poor SHs produce maize in food insecure zones at a larger scale and wheat in drought prone areas of barind tract areas at a limited scale. Other crops that the SHs produce are jute, sweet potato, pulses, spices, sugarcane, mung bean, and several types of vegetables. Most of the poor SHs are engaged in non-crop farming, include poultry and cattle rearing, beef fattening, goat rearing, fruit gardening, commercial fishing, and plantations. Raising poultry is a common non-crop practice among SHs, for the purpose of both consumption and commerce. Fishing is mostly done by poor SHs who live in the coastal belt areas. Poor SHs are engaged in non-agricultural enterprises/businesses, like renting tractors and spray machines, working in groceries and sweet shops, or serving as local transport drivers (korimon). The wage employment opportunities available in certain areas for poor SHs are day labor (e.g., agricultural day labor or work in a break field), masonry, rickshaw pulling, or wood cutting. In-country migration is familiar among the poor SHs. In a particular time of the year, they migrate from their own areas to different areas so as to be able to earn additional income for their livelihoods and purchae agricultural inputs. While Rajibpur and Porsha's SH household members don't migrate to other countries, members from the other three sub-districts do migrate, especially in the Middle East and southeast Asia (Malaysia) in limited scale.

The sample for this study was drawn from the population of poor SHs, and thus, their income is naturally very low compared to the national rural average and also the national rural average of poor households. As shown in qualitative investigation, their income comes mainly from that of farm and non-farm day labor and cereal crop farming (Table 16.8). The income differences are observed along the different strata of poor SHs. While ultra-poor SHs' income is differentiated from that of the medial and subjacent poor mainly by the income from the cereal crop and day-labor, and also partly from non-cereal crop income, the subjacent poor SHs' income is also differentiated from business income. That means that the medial poor and subjacent poor SHs, when compared to ultra-poor SHs, are taking some advantage of livelihood opportunities other than cereal-based farming. However, compared to the livelihood opportunities available in a typical advanced rural 


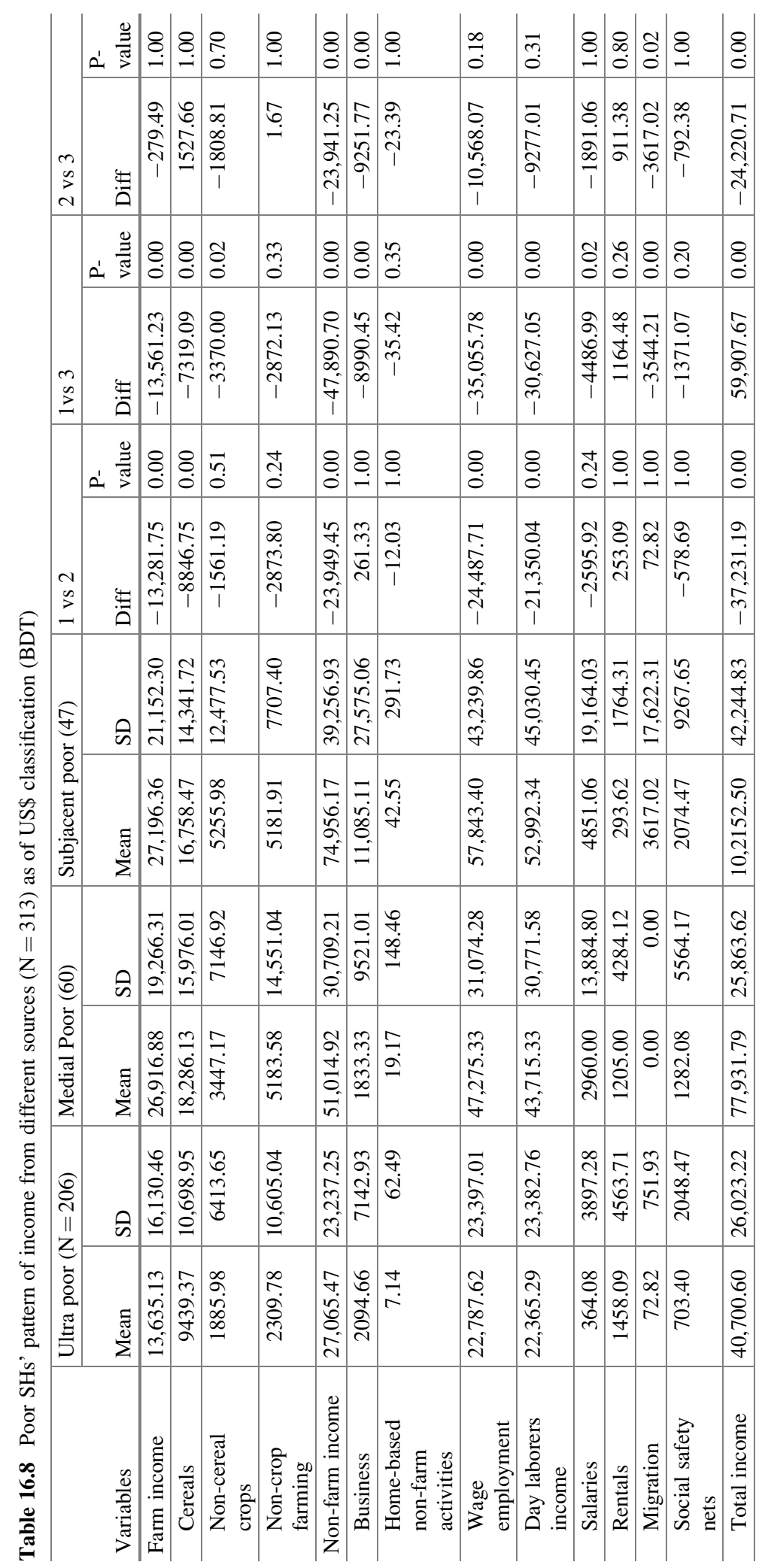


location, the income sources for poor SHs are limited only by the low productive nature of their activities. Thus, it is evident that the poor SHs in those areas are marginalized not only in the national context but also within the community.

\section{Segmentation of Poor SHs: Findings from Cluster Analysis}

To suggest which types of agricultural growth productivity program seem most promising for the improvement of agriculture and livelihoods of poor SHs in the marginality hotspots with agricultural potential in Bangladesh, we used cluster analysis to group the poor SHs according to appropriate dimensions leading to different strategic options. For this purpose, cluster analysis (a major technique for classifying data) is used. Cluster analysis assigns observations to groups (clusters) so that observations within each group are similar to one another with respect to variables or attributes of interest and each group stands apart from one another. In other words, it divides the observations into homogeneous and distinct groups. This is achieved by assigning all similar observations according to the degree of proximity (closeness) among the cluster elements by calculating the shortest possible distance between observations, referred to as the Euclidean distance. The Euclidean distance between observations $\left\{X_{1 i}, X_{2 i}, \ldots, X_{k i}\right\}$ and $\left\{X_{1 j}, X_{2 j}, \ldots, X_{k j}\right\}$ is estimated as:

$$
\mathrm{D}(\mathrm{i}, \mathrm{j})=\sqrt{\left(X_{1 i}-X_{1 j}\right)^{2}+\left(X_{2 i}-X_{2 j}\right)^{2}+\ldots\left(X_{k i}-X_{k j}\right)^{2}} .
$$

Observations with the closest distance are then grouped into one cluster. Allocation of the different strategic options to the farmers is done using both hierarchal and k-means cluster analysis. At first, cluster analyses are performed using a sequence of a common hierarchal and exchange algorithm using variables and attributes containing both dichotomous and categorical values. A cluster dendogram (cluster tree) reveals the appropriate number of clusters (in our case, 5). Then, we used K-means clustering, which aims to partition 313 observations into 5 clusters in which each observation belongs to the cluster with the nearest mean. K-means cluster analysis is a well-accepted exploratory statistical technique in social science research that creates natural, internally similar groups from rating scale questionnaire data. The statistical program identifies the centroid for each cluster by running the algorithm until a stable solution with minimum variability within each cluster and maximum variability between each cluster results. Through the focus group interviews and key informant discussions, the respondents are characterized into five strategic groups (Table 16.9). Based on the findings, the clusters are homogeneous in the sense that most are male-headed, have a relatively small family size, represent a very low number of schooling years, have similar non-land agricultural productive assets, have a low per capita income, and have insignificant salaried and remittance income, as well as all clusters benefitting from some form of social 
Table 16.9 Segmentation of poor SHs in marginal sub-districts in Bangladesh 2012-2013 $(\mathrm{N}=313)$ : Results of cluster analysis

\begin{tabular}{|c|c|c|c|}
\hline Clusters & $\begin{array}{l}\text { Freq. } \\
(\%)\end{array}$ & Characteristics & Strategic options \\
\hline 1 & $\begin{array}{l}36 \\
(11.5)\end{array}$ & $\begin{array}{l}\text { Farm size medium, CI low, moderate ownership } \\
\text { of the land, everybody sells their produce, } \\
\text { non-land physical assets and household durables } \\
\text { high, cereal income medium, other crop income } \\
\text { high, business and day labor income medium, } \\
\text { savings low, cereal technology adoption low, } \\
\text { access to the cereal inputs/markets low }\end{array}$ & $\begin{array}{l}\text { Non-cereal crops and } \\
\text { day labor }\end{array}$ \\
\hline 2 & $\begin{array}{l}107 \\
(34.19)\end{array}$ & $\begin{array}{l}\text { Zero ownership of the land but farm size high } \\
\text { (good access to the tenancy market), CI low, } \\
\text { about } 75 \% \text { sell their produce, non-land physical } \\
\text { assets low and household durables medium, } \\
\text { cereal income high, other crop income moderate, } \\
\text { no business income but day labor income high, } \\
\text { savings medium, cereal technology adoption } \\
\text { medium, access to cereal inputs/markets } \\
\text { medium }\end{array}$ & $\begin{array}{l}\text { Both cereal and } \\
\text { non-cereal crops and } \\
\text { day labor }\end{array}$ \\
\hline 3 & $\begin{array}{l}98 \\
(31.31)\end{array}$ & $\begin{array}{l}\text { Farm size high, CI high, high ownership of the } \\
\text { land, almost everybody sells their produce, } \\
\text { non-land physical assets and household durables } \\
\text { high, cereal income high, other crop, business } \\
\text { and day labor income medium, savings low, } \\
\text { cereal technology adoption high, access to cereal } \\
\text { inputs/markets high }\end{array}$ & Cereal crops \\
\hline 4 & $\begin{array}{l}33 \\
(10.54)\end{array}$ & $\begin{array}{l}\text { Farm size low, CI low, low ownership of the } \\
\text { land, about } 23 \% \text { sell their produce, non-land } \\
\text { physical assets and household durables low, crop } \\
\text { income low, business income moderate but day } \\
\text { labor income high, savings low, cereal technol- } \\
\text { ogy adoption medium, access to cereal inputs } \\
\text { medium but output market low }\end{array}$ & Day labor, business \\
\hline 5 & $\begin{array}{l}39 \\
(12.46)\end{array}$ & $\begin{array}{l}\text { Farm size medium, CI medium, low ownership } \\
\text { of the land, about } 62 \% \text { sell their produce, } \\
\text { non-land physical assets and household durables } \\
\text { medium, cereal income medium but other crop } \\
\text { income low, business income high but day labor } \\
\text { income low, savings high, cereal technology } \\
\text { adoption medium, access to cereal inputs } \\
\text { medium but output market medium }\end{array}$ & $\begin{array}{l}\text { Business and cereal } \\
\text { crops }\end{array}$ \\
\hline Total & 313 & & \\
\hline
\end{tabular}

safety net and having taken out some form of loan. On the other hand, ownership of the land, farm size, cropping intensity, agricultural crop sales, household durables, cereal income, other crop income, business income, day labor income, household savings, cereal technology adoption, access to the agricultural market, play a 
decisive role in making the clusters distinct from one another. Thus, among the five groups of poor SHs, non-cereal and non crop farming with day labor and day labor with business could be appropriate strategic options for two groups, while the other three appropriate strategic options could be farming (crop and non-crop) with day labor, cereal crops, and business with cereal crops (Table 16.10). The meanings of these results are: (1) For a productivity growth program geared towards individual poor SHs, day - labor cannot be a strategic option, although poor SHs naturally utilize it as a survival strategy; (2) Among poor SHs, though about $97.78 \%$ of households cultivate cereals as a way of accruing the majority of their household's income share, they are still living under the poverty line, and subsequently need alternative options that could increase their income and livelihood security. Thus, only cereal-based productivity programs will be insufficient for improving the food and livelihood security of poor SHs, and the growth productivity program should be designed in a way that the SHs could have the opportunity to explore their human capability in farming (cereal and non-cereal crops and non-crop farming) and business that creates both backward and forward linkages with those farming in the locality. Therefore, we should extend our focus on crop technology innovations to include non-crop farming and non-farm businesses that could better link SHs with the market.

\section{Technology Innovations for Poor Small Holders and the Barriers: Beyond Crop Technology Innovations}

Initially, we focused on cereal crop technology innovations; later, it was expanded from cereal crops to all crops, non-crop framing and non-farm innovations required for growth productivity programs for poor SHs in the selected areas. For identifying technological innovations, we did not follow the traditional pipe-line approach, that is, scientists develop technology and then it is given to the extension agents for adoption among the farmers. Rather, we took a bottom-up approach that matched available technologies with the needs, aspirations and potentials of poor SHs and the projected costs (barriers), i.e, the matching available technological innovations usually require to enable conditions to work for poor SHs. In our approach, the focus of the innovation packages should be related to current farming practices and cropping technology use by SHs covering all stages of production (pre-production, production, harvesting, processing and marketing) - it could be newly introduced goods and services for most of the farmers but should be readily available in the locality (despite having potential, some farmers are adopting certain technology innovations, others are not; in a similar context, some farmers are getting very good returns, others are getting far less).

Following literature/document review, and consultation with scientists, both at national and regional levels, and local level extension workers/officials from both 


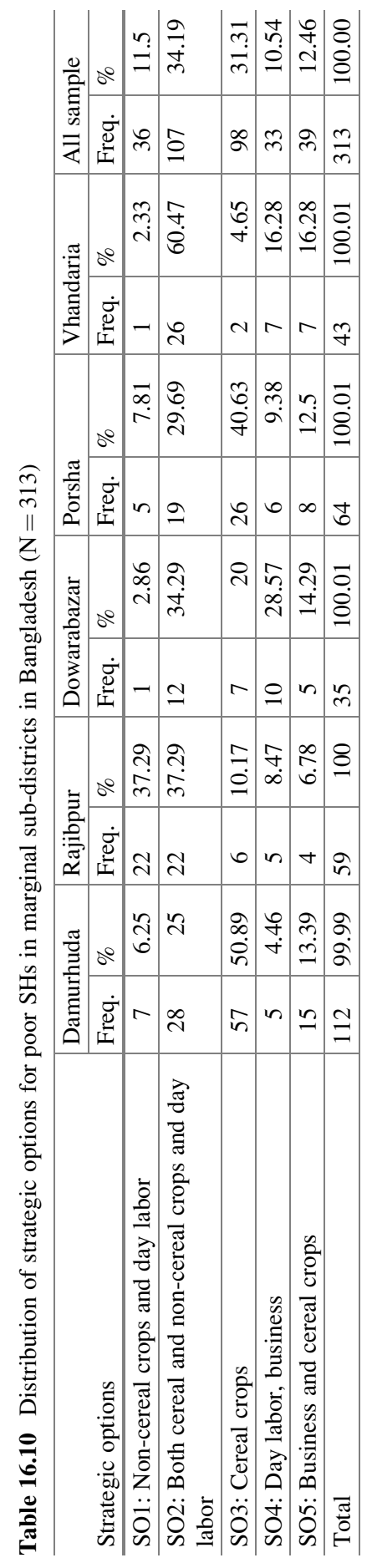


GOs and NGOs, we prepared a list of more than 50 technology innovations (Annex 3 ) and conducted a perception study. The perception study addressed several key questions: (1) Are the SHs aware of this technological innovation? (2) How many SHs of those who are aware are currently using it? (3) Which technologies (for the farmers who are aware) are most important?

Poor perception by SHs about those technologies (following the frequencies and percentages of their responses) can be grouped in several ways: (1) all three indicators, awareness, adoption and further importance of certain technologies (for example, power tiller/tractor, machine for pesticide use, seed plantation in line with definite spacing), are very high, which means that even though these technologies have already been intensively adopted, awareness of their necessity prevails; (2) for some technologies (rice mill (diesel driven), shallow tube well (STW), rice mill (electricity driven), etc.), awareness and importance are high but adoption is not high, which means that adoption of the second group of technologies needs to increase significantly; (3) for some technologies, awareness, adoption and importance are all low - most of these technologies have only recently been developed at the research station, and the farmers in those areas are not quite aware of their importance. At the second stage, mainly in regard to the third group of technologies, we consulted with BRAC in-house technology experts/practitioners who are knowledgeable about those technologies and those study areas, and found some technologies that could be useful, for example, short-duration aman rice varieties, hybrid maize and stress-tolerant wheat varieties, handy kits for using guti urea, etc. At the final stage, we again validated our study results with the local level stakeholders, for example, extension workers (both public and NGOs), input dealers, processors, model farmers, poor SHs and made the lists of technological innovations for the future growth productivity program (Table 16.11).

\section{Conclusions}

Under a collaborative project entitled "Technology assessment and farm household segmentation for inclusive poverty reduction and sustainable productivity growth in agriculture (TIGA)" conducted by the Center for Development Research (ZEF), Bonn, in four partner countries from South Asia and Sub-Saharan Africa, this paper discusses the results generated from the Bangladesh country study. Following a marginality approach developed at ZEF, we identified five marginal sub-districts in Bangladesh, i.e., underperforming areas in which the prevalence of poverty and other socio-economic dimensions of marginality are high and agricultural potential is also high, since, in such areas, yield gaps (potential minus actual yields) are high and productivity gains (of main staple crops) are likely to be achieved. Then, we conducted a household census of 5,855 households in 16 marginal villages from those five sub-districts and drew a sample of 357 poor SHs for an in-depth quantitative sample survey. Some qualitative surveys (focus group discussions, in-depth interviews) were also conducted. Then, we developed the analytical 


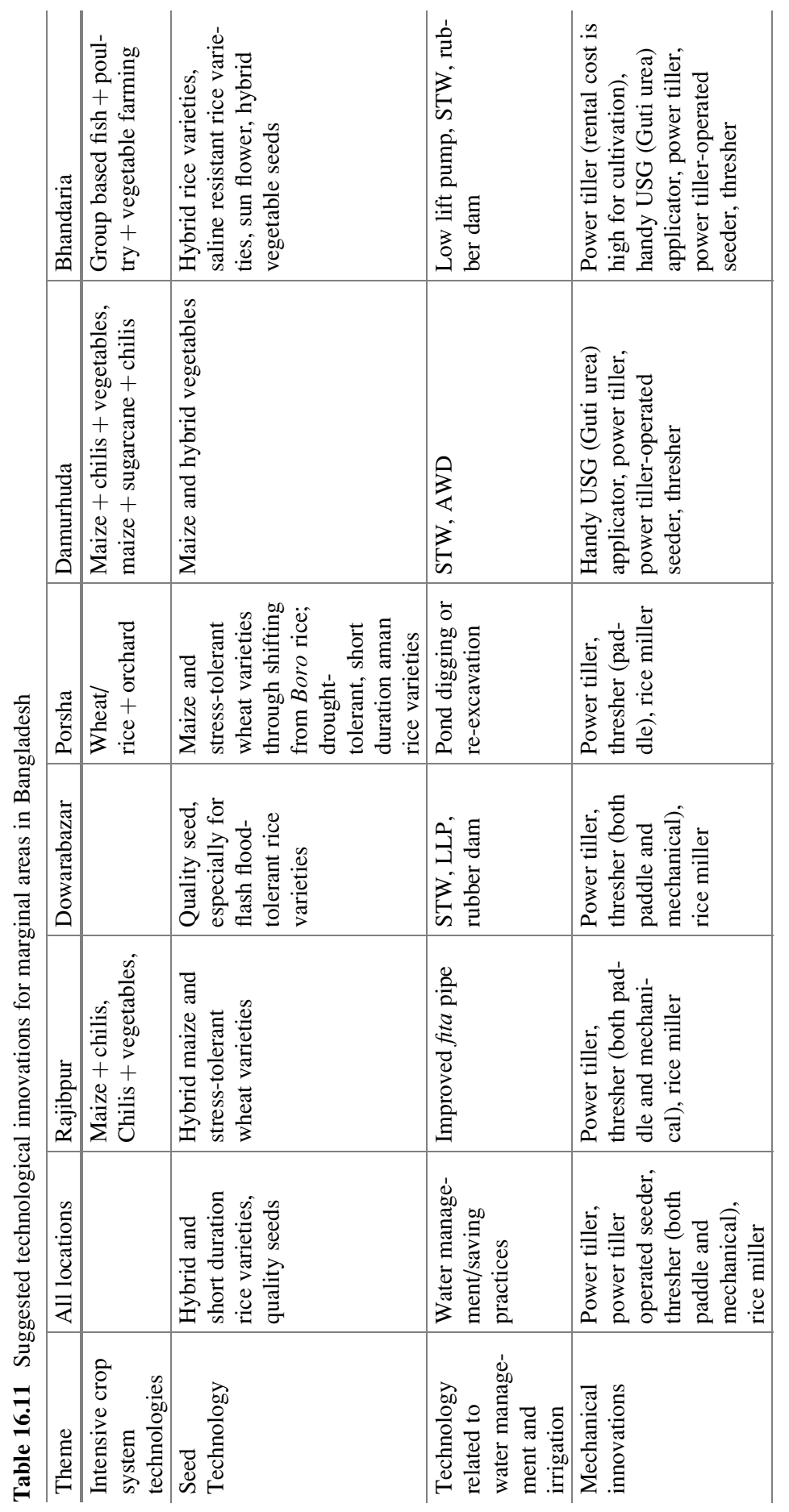




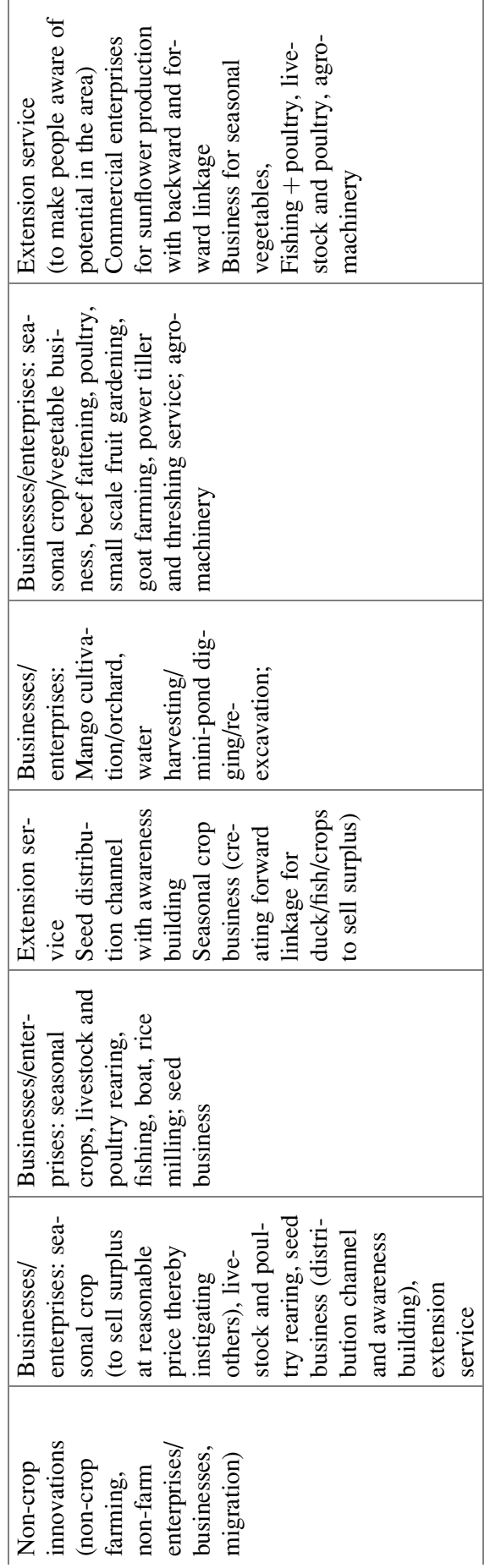


methodology to create a thorough understanding of the interactions between technology needs, farming systems, ecological resources and poverty characteristics in the different strata of the poor SHs, and to link these insights with technology assessments in order to guide action for overcoming current barriers to technology access and adoption under the common approach for technological innovations for inclusive growth in agriculture developed at ZEF jointly with its partners. Results suggest that five marginal sub-districts with agricultural potential are very different from each other. Sufficient potential exists in those sub-districts, and enough scope to develop that potential, to ensure farm intensification and livelihood diversification. Regarding adverse agro-ecological vulnerability, almost all five areas are facing to some extent, natural calamities (flood, drought, salinity by tidal flow). This discourages poor SHs from thinking that innovative processes and technology might be useful for their agricultural intensification and livelihoods. Poor SHs' income mainly accrues from cereal crop income and low productive non-farm sources (say, agricultural day labor) and their capital bases being very poor do not differ significantly from different strata quantitatively, though qualitatively, some differences among the capital bases have been observed. Cluster analysis gives meaningful segmentation of poor SHs. Development strategies should focus on three pathways: agricultural intensification, income diversification and agricultural diversification based on options available for the SHs in the localities. Cerealbased technology under agricultural innovations could be part of the solution, but that could also be integrated with other income diversification and agricultural diversification strategies. Intensive crop system, hybrid seeds, water management technologies, non-crop farming, non-farm enterprises/businesses are the suggested potential technological innovations for the study areas. The technological innovations could be promoted through introducing strategic development programs that include promotion of crop and non-crop farming production and related (backward and forward) non-farm businesses in the localities.

Open Access This chapter is distributed under the terms of the Creative Commons AttributionNoncommercial 2.5 License (http://creativecommons.org/licenses/by-nc/2.5/) which permits any noncommercial use, distribution, and reproduction in any medium, provided the original author(s) and source are credited.

The images or other third party material in this chapter are included in the work's Creative Commons license, unless indicated otherwise in the credit line; if such material is not included in the work's Creative Commons license and the respective action is not permitted by statutory regulation, users will need to obtain permission from the license holder to duplicate, adapt or reproduce the material. 


\section{Annex 1: Characteristics of Poor SHs with Regard to Crop Technology Innovations in Marginality Hotspots with Agricultural Potential in Bangladesh}

\begin{tabular}{|c|c|c|c|}
\hline \multirow{2}{*}{$\begin{array}{l}\text { Areas/sub- } \\
\text { districts/villages }\end{array}$} & \multicolumn{3}{|l|}{ Poverty strata } \\
\hline & Subjacent poor & Medial poor & Ultra poor \\
\hline $\begin{array}{l}\text { Charland/ } \\
\text { Rajibpur/ } \\
\text { Borober }\end{array}$ & $\begin{array}{l}\text { Own some agricultural } \\
\text { land and do farming } \\
\text { mainly through tenancy } \\
\text { Cropping pattern: } \\
\quad \text { Boro rice/Chilis/Vege- } \\
\text { tables- Maize/Maize+ } \\
\text { vegetables + Chilis/veg- } \\
\text { etables/Chilis+ Vegeta- } \\
\text { bles- Vegetables/ } \\
\text { Sugarcane+ Maize/Nuts/ } \\
\text { Chilis+ Vegetables } \\
\text { Non crop farming: } \\
\quad \text { Poultry and cattle } \\
\text { rearing, beef fattening, } \\
\text { fruit gardening, etc. } \\
\text { Affected by riverbank } \\
\text { erosion } \\
\text { Physically able to do } \\
\text { hard work }\end{array}$ & $\begin{array}{l}\text { Agricultural day } \\
\text { labor and farming, } \\
\text { mainly through ten- } \\
\text { ancy, are the main } \\
\text { occupation } \\
\text { Cropping pattern: } \\
\quad \text { Bororice-Maize- } \\
\text { Vegetables, Mung } \\
\text { Beans/Maize } \\
\text { Non-crop farming: } \\
\text { poultry and cattle } \\
\text { farming } \\
\text { Have no homestead } \\
\text { land, live on lease } \\
\text { land } \\
\text { Physically able to do } \\
\text { hard work }\end{array}$ & $\begin{array}{l}\text { Main occupation is } \\
\text { agricultural day labo } \\
\text { but very few do tenant } \\
\text { farming } \\
\text { Cropping pattern: } \\
\quad \text { Sugar Cane/Boro } \\
\text { rice-vegetables/jute/ } \\
\text { Maize-vegetables/ } \\
\text { maize/maize+ } \\
\text { sugarcane+ chilis } \\
\text { Non-crop farming: Nil } \\
\text { Have no homestead } \\
\text { Mostly old people } \\
\text { (separated from their } \\
\text { children)- physically } \\
\text { not very able to do } \\
\text { hard work }\end{array}$ \\
\hline $\begin{array}{l}\text { Haor basin/ } \\
\text { Dowarabazar/ } \\
\text { Poromessorpur }\end{array}$ & $\begin{array}{l}\text { Own agricultural land } \\
<3 \text { acres } \\
\text { Cropping pattern: } \\
\quad \text { Boro rice/ Vegeta- } \\
\text { bles- Fallow-Aman rice } \\
\text { Non-crop farming: nil } \\
\text { Level of education: } \\
\text { above primary level } \\
\text { Influential and respect- } \\
\text { able in the village }\end{array}$ & $\begin{array}{l}\text { Own agricultural land } \\
<2 \text { acres } \\
\text { Cropping pattern: } \\
\text { Boro rice/vegeta- } \\
\text { bles- Fallow-Aman } \\
\text { rice } \\
\text { Non-crop farming: } \\
\text { poultry (consump- } \\
\text { tion) } \\
\text { Level of education: } \\
\text { below primary level } \\
\text { Physically not well fit } \\
\text { to do hard work }\end{array}$ & $\begin{array}{l}\text { Own agricultural } \\
\text { land }<1 \text { acre and some } \\
\text { people do not own } \\
\text { even homestead land } \\
\text { Cropping pattern: } \\
\text { Boro rice/vegetables- } \\
\text { Fallow-Aman/Fallow } \\
\text { Non-crop farming: } \\
\text { poultry (consumption) } \\
\text { Level of education: } \\
\text { illiterate } \\
\text { Aged and physically } \\
\text { not fit to do hard work }\end{array}$ \\
\hline $\begin{array}{l}\text { Barind tract/ } \\
\text { Porsha/ } \\
\text { Bhobanipur }\end{array}$ & $\begin{array}{l}\text { Own agricultural land - } \\
\text { 1-1.5 acres } \\
\text { Cropping pattern: } \\
\text { Boro rice/Wheat-Aus/ } \\
\text { vegetables/Jute- Aman/ } \\
\text { Potatoes } \\
\text { Non-crop farming: } \\
\text { gardening }\end{array}$ & $\begin{array}{l}\text { No agricultural land } \\
\text { except homestead } \\
\text { land } \\
\text { Farm size through } \\
\text { tenancy }<1 \text { acre } \\
\text { Cropping pattern: } \\
\quad \text { Boro rice/wheat- } \\
\text { vegetables-Aman/ } \\
\text { vegetables } \\
\text { Non-crop farming: } \\
\text { gardening, commer- } \\
\text { cial fishing }\end{array}$ & $\begin{array}{l}\text { No agricultural land, } \\
\text { not even homestead } \\
\text { Main occupation is } \\
\text { agricultural day labor } \\
\text { but very few do tenant } \\
\text { farming } \\
\text { Cropping pattern: } \\
\text { Boro/Fallow/ } \\
\text { Wheat-Aus/Fallow- } \\
\text { Aman/Vegetables } \\
\text { Non-crop farming: } \\
\text { gardening, commercial } \\
\text { fishing }\end{array}$ \\
\hline $\begin{array}{l}\text { Barind tract and } \\
\text { food insecure }\end{array}$ & $\begin{array}{l}\text { Amount of owned land } \\
<0.70 \text { acre and able to }\end{array}$ & $\begin{array}{l}\text { Amount of owned } \\
\text { land }<0.30 \text { acre }\end{array}$ & $\begin{array}{l}\text { Own land }<0.05 \text { acre } \\
\text { Main occupation is }\end{array}$ \\
\hline
\end{tabular}




\begin{tabular}{|c|c|c|c|}
\hline \multirow{2}{*}{$\begin{array}{l}\text { Areas/sub- } \\
\text { districts/villages }\end{array}$} & \multicolumn{3}{|l|}{ Poverty strata } \\
\hline & Subjacent poor & Medial poor & Ultra poor \\
\hline $\begin{array}{l}\text { zone/ } \\
\text { Damurhuda/ } \\
\text { ChotoDudpatila }\end{array}$ & $\begin{array}{l}\text { take some land on rented } \\
\text { in. } \\
\text { Cropping pattern: } \\
\quad \text { Boro rice/chilis/vege- } \\
\text { tables- maize/maize+ } \\
\text { vegetables + chilis/vege- } \\
\text { tables/chilis+ vegeta- } \\
\text { bles- vegetables/ } \\
\text { sugarcane+ maize/nuts/ } \\
\text { chilis+ vegetables } \\
\text { Non-crop farming: poul- } \\
\text { try and cow fattening } \\
\text { Unable to manage } \\
\text { household expenditure by } \\
\text { farming and so day labor } \\
\text { is needed for livelihood }\end{array}$ & $\begin{array}{l}\text { Difficult to take land } \\
\text { as tenant } \\
\text { Cropping pattern: } \\
\text { Boro-Hybrid rice/ } \\
\text { Maize-Vegetables, } \\
\text { Mung Beans/Maize } \\
\text { Non-crop farming: } \\
\text { Fruit gardening } \\
\text { (small scale), poultry, } \\
\text { cow fattening, goat } \\
\text { farming }\end{array}$ & $\begin{array}{l}\text { agricultural day labor } \\
\text { but very few do tenant } \\
\text { farming } \\
\text { Unable to take loan to } \\
\text { do agriculture } \\
\text { Cropping pattern: } \\
\quad \text { Sugar Cane/Boro } \\
\text { rice-vegetables/jute/ } \\
\text { maize- vegetables/ } \\
\text { maize/ maize+ } \\
\text { sugarcane+ chilis } \\
\text { Non-crop farming: } \\
\text { poultry, goat farming }\end{array}$ \\
\hline $\begin{array}{l}\text { Coastal belt/ } \\
\text { Bhandaria/ } \\
\text { OttorJunia }\end{array}$ & $\begin{array}{l}\text { Own farm land: } 30-40 \\
\text { decimals } \\
\text { Cropping pattern: } \\
\quad \text { Boro rice/vegetables } \\
\text { (hybrid)-Aus (fallow)- } \\
\text { Aman rice/fallow/ } \\
\text { Spices/lentils } \\
\text { Non-crop farming: } \\
\quad \text { Fishing + poultry, } \\
\text { fruit gardening } \\
\text { Level of education: } \\
\text { above primary level } \\
\text { Aware and always trying } \\
\text { to change economic con- } \\
\text { dition } \\
\text { High communication } \\
\text { skills and maintain good } \\
\text { relationship with agricul- } \\
\text { tural extension officers/ } \\
\text { workers } \\
\text { Capable of giving fertil- } \\
\text { izer, irrigation, and pes- } \\
\text { ticides in time } \\
\text { Receive credit from dif- } \\
\text { ferent sources and repay } \\
\text { the loan on time } \\
\text {-Everyone has mobile } \\
\text { phone } \\
\text {-Send children to school }\end{array}$ & $\begin{array}{l}\text { Own farm land } \\
\text { (excluding home- } \\
\text { stead): } 10-20 \text { decs. } \\
\text { Cropping pattern } \\
\quad \text { Boro rice-Aus (fal- } \\
\text { low)- aman rice/ } \\
\text { spices/lentils/robi } \\
\text { Crop } \\
\text { Non-crop farming: } \\
\quad \text { Fishing, poultry, } \\
\text { fattening beef cattle } \\
\text { Level of education: } \\
\text { primary level } \\
\text { Rate of return on } \\
\text { investment is rela- } \\
\text { tively better than } \\
\text { ultra-poor } \\
\text { Have enough agricul- } \\
\text { tural knowledge and } \\
\text { experiences } \\
\text { Use traditional tech- } \\
\text { nology in farming } \\
\text { Able to deposit a } \\
\text { small amount for } \\
\text { renting a piece of land } \\
\text {-Preserve seed for } \\
\text { next crop season }\end{array}$ & $\begin{array}{l}\text { Have no farm land } \\
\text { except homestead } \\
\text { Cropping pattern: } \\
\quad \text { Bororice-Ausrice- } \\
\text { Aman+vegetables+s- } \\
\text { pices+lentils } \\
\text { Non-crop farming: } \\
\quad \text { Fishing, poultry, } \\
\text { fattening } \\
\text { beef cattle } \\
\text { Illiterate and unable to } \\
\text { adapt to new technol- } \\
\text { ogy } \\
\text { Limited opportunity to } \\
\text { improve economic } \\
\text { conditions } \\
\text { Partly involved in } \\
\text { agriculture and poor } \\
\text { social capital } \\
\text { Family size: usually } \\
\text { large }\end{array}$ \\
\hline
\end{tabular}

Source: Extracts from qualitative survey conducted for TIGA Bangladesh: April 2013

\section{Annex 2: Strata of Specific Livelihood Options for Poor SHs in Marginality Hotspots in Bangladesh}




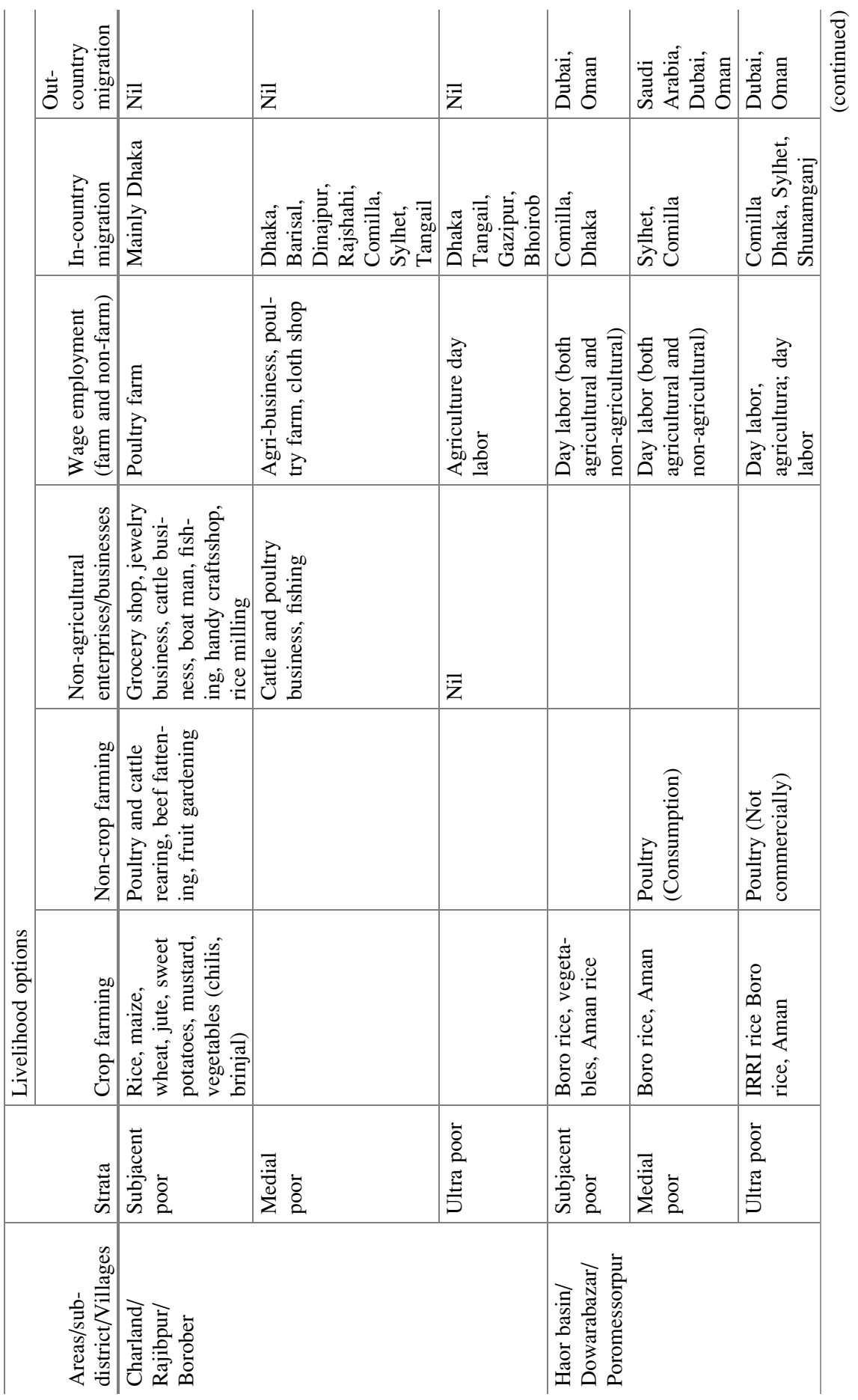




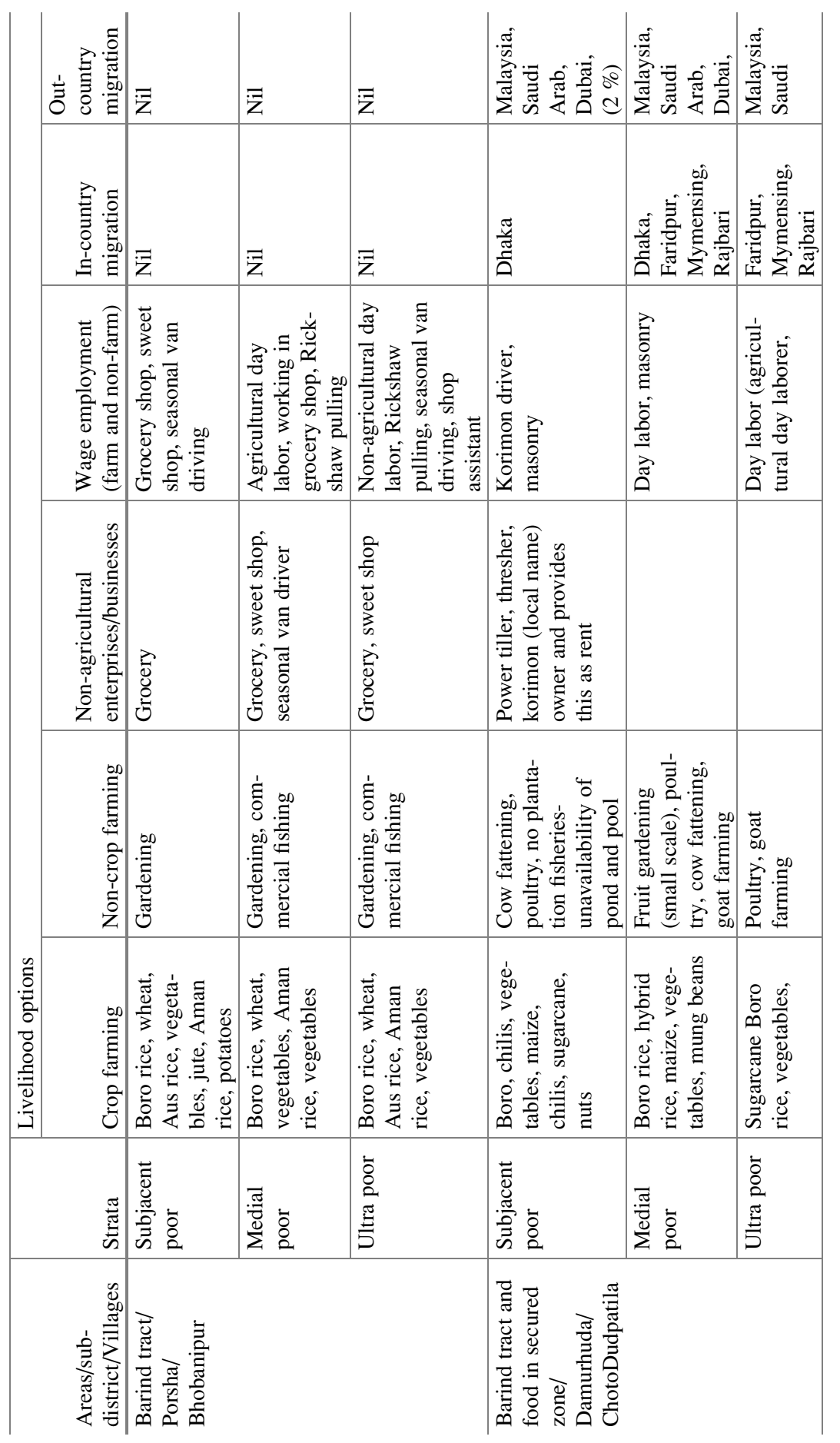




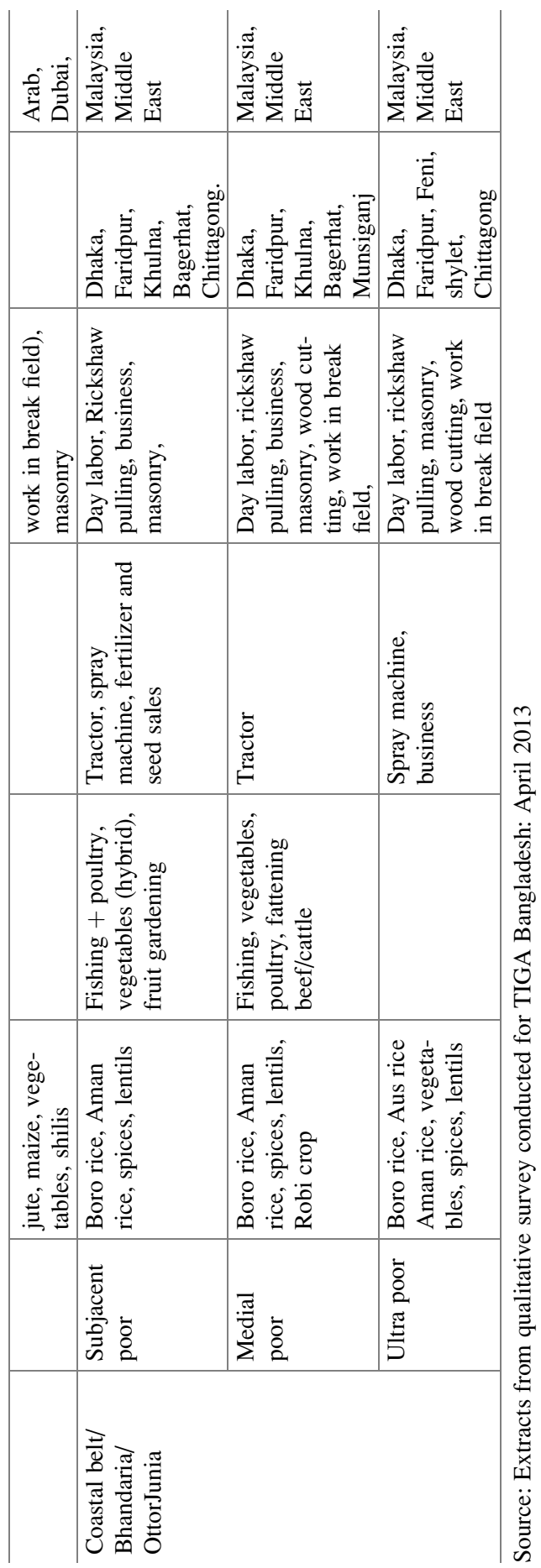




\section{Annex 3: Technology Innovations for Marginal Areas: Results from the TIGA Perception Study 2013}

\begin{tabular}{|c|c|c|c|}
\hline \multicolumn{4}{|c|}{$\begin{array}{l}\text { 1. All three indicators- awareness, adoption and further importance of some technologies are } \\
\text { very high }\end{array}$} \\
\hline $\begin{array}{l}\text { Power tiller/tractor for preperation of } \\
\text { land }\end{array}$ & 98.88 & 95.52 & 95.52 \\
\hline Machine for pesticide use & 79.27 & 75.35 & 75.63 \\
\hline $\begin{array}{l}\text { Seed plantation in line with definite } \\
\text { spacing }\end{array}$ & 83.19 & 74.79 & 75.07 \\
\hline Rice mill (diesel-driven) & 88.24 & 69.19 & 70.59 \\
\hline Shallow tubewell (STW) & 85.99 & 53.22 & 68.35 \\
\hline Rice mill (electricity-driven) & 84.03 & 52.38 & 63.03 \\
\hline Thresher/Bomaor Auto Machine & 63.31 & 49.30 & 56.58 \\
\hline Deep tubewell (DTW) & 67.51 & 38.10 & 52.38 \\
\hline Irrigation in dry season & 42.3 & 35.29 & 39.22 \\
\hline Herbicides & 34.45 & 27.45 & 28.57 \\
\hline Pedal thresher & 35.01 & 25.77 & 26.05 \\
\hline Irrigation by Fita Pipe & 25.21 & 17.65 & 18.49 \\
\hline
\end{tabular}

2. Awareness and importance are high but adoption is not high

\begin{tabular}{|c|c|c|c|}
\hline Hybrid paddy & 84.03 & 27.45 & 61.9 \\
\hline $\begin{array}{l}\text { Irrigation from pond/river using } \\
\text { power driven pump (LLP) }\end{array}$ & 64.99 & 41.18 & 50.7 \\
\hline $\begin{array}{l}\text { Using money instead ofcrops in share } \\
\text { cropping }\end{array}$ & 46.22 & 33.05 & 35.29 \\
\hline Hybrid maize & 36.69 & 16.25 & 28.57 \\
\hline HYV wheat & 40.62 & 15.41 & 26.89 \\
\hline $\begin{array}{l}\text { Plastic container/drum/polythene for } \\
\text { seed collection }\end{array}$ & 26.61 & 22.41 & 25.21 \\
\hline Compost & 30.53 & 17.65 & 22.41 \\
\hline $\begin{array}{l}\text { SRI in rice cultivation (young seed- } \\
\text { ling, half plant in one bundle, space } \\
\text { between bundles, irregular irrigation) }\end{array}$ & 27.17 & 18.49 & 22.13 \\
\hline
\end{tabular}

3. Awareness, adoption and importance are all low

\begin{tabular}{l|l|l|l}
\hline Drugs for seed preservation & 20.45 & 10.36 & 16.25 \\
\hline Guti urea (urea tablet/USP/UDP) & 27.73 & 5.60 & 13.17 \\
\hline $\begin{array}{l}\text { Rainwater reserved by pond digging } \\
\text { and irrigation in dry season }\end{array}$ & 21.01 & 6.44 & 10.36 \\
\hline Aromatic Boro variety & 12.61 & 5.60 & 9.52 \\
\hline Short-duration Aman variety & 12.04 & 3.92 & 7 \\
\hline $\begin{array}{l}\text { Mobile phone for exchanging agri- } \\
\text { cultural information (information }\end{array}$ & 6.44 & 4.48 & 5.32 \\
\hline
\end{tabular}




\begin{tabular}{|c|c|c|c|}
\hline Technologies & $\begin{array}{l}\text { Are the } \\
\text { SHs aware } \\
\text { of this? }(\%)\end{array}$ & $\begin{array}{l}\text { What } \% \text { of the } \\
\text { aware SHs are } \\
\text { using it? }\end{array}$ & $\begin{array}{l}\text { Which technologies } \\
\text { (for the aware farmers) } \\
\text { are most imporant? }\end{array}$ \\
\hline \multicolumn{4}{|l|}{$\begin{array}{l}\text { dissemination, price of fertilizer, } \\
\text { price of crop) }\end{array}$} \\
\hline Inter cropping of maize & 6.72 & 1.12 & 4.76 \\
\hline Rice-fish mixed cropping & 10.92 & 0.84 & 3.92 \\
\hline $\begin{array}{l}\text { Using large water reservoir to hoard } \\
\text { rainwater for irrigation i n the dry } \\
\text { season }\end{array}$ & 5.04 & 1.96 & 2.52 \\
\hline $\begin{array}{l}\text { Irrigation by Barid Pipe/alternative } \\
\text { to Fita Pipe }\end{array}$ & 3.08 & 1.40 & 2.24 \\
\hline Mechine for using Guti urea & 4.2 & 1.68 & 2.24 \\
\hline Combined thresher & 6.44 & 3.36 & 3.92 \\
\hline Water tolerant Aman variety & 8.12 & 2.52 & 3.08 \\
\hline Inter cropping of rice & 4.76 & 0.28 & 2.52 \\
\hline $\begin{array}{l}\text { Seeder machine for land preparation, } \\
\text { seeding and weeding }\end{array}$ & 3.92 & 1.40 & 1.96 \\
\hline $\begin{array}{l}\text { Water hoarding using Ruber Drum } \\
\text { Reservoir }\end{array}$ & 3.08 & 1.68 & 1.96 \\
\hline Inter cropping of wheat & 1.68 & 0.28 & 1.4 \\
\hline $\begin{array}{l}\text { Bed } \mathrm{pl} \text { anter mechine for plant, fer- } \\
\text { tilizer and seeding }\end{array}$ & 2.52 & 0.84 & 1.12 \\
\hline Drought-tolerant wheat variety & 1.4 & 1.12 & 1.12 \\
\hline IPM (Integrated Pest Management) & 1.96 & 0.56 & 1.12 \\
\hline $\begin{array}{l}\text { If you become aware of any technol- } \\
\text { ogy which is not mentioned above } \\
\text { (specify....) }\end{array}$ & 1.12 & 0.84 & 1.12 \\
\hline $\begin{array}{l}\text { Drought-tolerant and short-duration } \\
\text { A man variety }\end{array}$ & 1.96 & 0.56 & 0.84 \\
\hline $\begin{array}{l}\text { Drought-tolerant maize variety } \\
\text { (instead of paddy) }\end{array}$ & 0.56 & 0.56 & 0.56 \\
\hline Short-duration maize variety & 0.84 & 0.56 & 0.56 \\
\hline Early maturing maize variety & 0.84 & 0.56 & 0.56 \\
\hline Water-tolerant maize variety & 0.84 & 0.00 & 0.56 \\
\hline $\begin{array}{l}\text { Introducing more short-duration crop } \\
\text { variety }\end{array}$ & 0.56 & 0.28 & 0.28 \\
\hline Leaf color chart (LCC) & 0.56 & 0.56 & 0.28 \\
\hline Drought-tolerant wheat variety & 1.4 & 0.00 & 0 \\
\hline Short-duration wheat variety & & 0.00 & 0 \\
\hline Early ma turing wheat variety & 0.28 & 0.00 & 0 \\
\hline Magic Pipe - (AWD) & 0.56 & 0.56 & 0 \\
\hline
\end{tabular}




\section{References}

Balen J, McManus DP, Li Y, Zhao Z, Yuan L, Utzinger J, Williams GM, Li Y, Ren M, Liu Z, Zhou J, Raso G (2010) Comparison of two approaches for measuring household wealth via an asset-based index in rural and peri-urban settings of Hunan province, People's Republic of China. Emerg Themes Epidemiol 7(1):7. doi:10.1186/1742-7622-7-7

BBS (2011) Report of the Household Income and Expenditure Survey 2010. Bangladesh Bureau of Statistics, Statistics Division, Ministry of Planning, Government of the People's Republic of Bangladesh, Dhaka

Carney D (ed) (1998) Sustainable livelihoods: what contribution can we make? Department for International Development, London

Conway G (1999) The doubly green revolution: food for all in the twenty-first century. Cornell University Press, Ithaca

DFID (1999) Sustainable livelihoods guidance sheets. Department for International Development, London

DFID (2000) Sustainable livelihoods guidance sheets. Department for International Development, London

Fan S, Hazell P (2000) Should developing countries invest more in less-favoured areas? An empirical analysis of rural India. Econ Polit Wkly 35(17):1455-1464

HKI, JPGSPH (2011) State of food security and nutrition in Bangladesh, 2010. Helen Keller International and James P Grant School of Public Health, Dhaka

Malek MA, Usami K (2010) Do the non-farm incomes really matter for poverty among small households in Rural Bangladesh? A case of advanced villages. J Dev Agric Econ 2(7):250-267

Malek MA, Hossain MA, Saha R, Gatzweiler FW (2013) Mapping marginality hotspots and agricultural potentials in Bangladesh. Working paper No. 114. Center for Development Research, Bonn

OECD (2001) Poverty reduction - the DAC guidelines. Organisation for Economic Co-operation and Development, Paris

Pender J (2007) Agricultural technology choices for poor farmers in less-favored areas of South and East Asia. IFPRI discussion paper 00709. International Food Policy Research Institute, Washington, DC

Pinstrup-Anderson P, Pandya-Lorch R (1994) Alleviating poverty, intensifying agriculture and effectively managing natural resources. Food agriculture and the environment discussion paper no 1. International Food Policy Research Institute, Washington, DC

Reardon T, Chen K, Minten B, Adriano L (2012) The quiet revolution in staple food value chainsEnter the Dragon, the Elephant, and the Tiger. Asian Development Bank and International Food Policy Research Institute, Manila/Washington, DC

Ruben R, Pender J, Kuyvenhoven A (2007) Sustainable poverty reduction in less-favoured areas: problem, options and strategies. In: Ruben R, Pender J, Kuyvenhoven A (eds) Sustainable poverty reduction in less favored areas. CABI, Wallingford

Rutstein S (1999) Health nutrition and population country fact sheets. DHS (Demographic and Health Surveys) Programm, Macro International, Calverton 